\title{
REFLECTION
}

\section{Affordable Care?}

\author{
Adam O. Goldstein, MD, MPH
}

Department of Family Medicine, University of North Carolina at Chapel Hill School of Medicine, Chapel Hill, North Carolina
Conflicts of interest: author reports none.

\section{CORRESPONDING AUTHOR}

Adam O. Goldstein, MD, MPH Department of Family Medicine UNC School of Medicine Chapel Hill, NC 27599-7595 aog@med.unc.edu

\begin{abstract}
Once a year, Stuart, a long-haul truck driver, visited a physician to get a signature on the forms that allowed him to continue driving his 18-wheeler. Over 8 years, he had never seen the same physician twice, in large part because of a lack of health insurance. Upon seeing him for the first time, I assured him that we could make financial arrangements, and he subsequently became my continuity patient. Two years later, we both looked forward to his impending 65th birthday, allowing Medicare to ease his fiscal health care burdens. His unexpected death made me ponder how a lack of access to affordable health care profoundly affects patients and their clinicians.
\end{abstract}

Ann Fam Med 2015;13:370-372. doi: 10.1370/afm.1806.

$\mathrm{H}$ ealth insurance was a luxury, Stuart immediately informed me at his first visit, long delayed because he lacked the disposable cash to pay up front as the clinic policy dictated. Once a year, like clockwork, he appeared with his Department of Transportation (DOT) forms, looking for a physician's signature attesting to his continued competence to drive the 18 -wheeler safely. While looking at the 100-plus questions on the form, I wondered if the different assessments of physical and psychological health would truly allow me enough knowledge to sign off on patient safety, much less know him as a person.

Tall and lean, Stuart stared at me intently. His strong opening words and laser-like eye connection told me that he was likely a no-nonsense kind of person. His posture was almost standoffish, he sat still, low, and with his back pressed solidly in the exam room chair, wiry legs extended and hands clasped firmly together. I initially mistook these behaviors as a desire for brevity as I thought about how to respond to his questions.

Like the previous 8 physicians whom Stuart had visited over the past 8 years, I was quite ready to assume that I knew his health history through a quick read of his electronic health record. Stuart had a history of high blood pressure, neither sufficiently controlled nor high enough to deny a signature giving license to work and drive, but certainly not within the normal range. Combined with his reticence to disclose other health details, this visit seemed like a potential quick visit, the brief 'catch-up' encounter in the otherwise always-running-a-little-behind clinic environment. Stuart waited patiently for me to ask him questions, complicit in our unspoken strategy of returning close-ended questions with yes or no answers to limit total clinic time. He did not change his posture, but his legs began to sway, almost imperceptibly at first, and then like a breeze, as if he was settling into the conversation-either that or he was simply getting a little annoyed.

Indeed, the visit would have been quite short had I not become curious as to why Stuart had not seen any physician twice in all his visits and why he never came back for follow-up despite our recommendations. His answer was short and to the point: "I don't have any health insurance." Pausing for a moment, I said it must be hard for him to be in this place and have to respond that way. It was a simple reflection, but it caused him to pause, and that was when our relationship began to change. 
His first words back were equally on target. "I know the longer I talk, the more I tell you, the more I explain, the higher your bill," he said. "So I say little, don't ask many questions, and nod my head frequently." Stuart then began to tell me about his extensive pain, occurring every day in his hands, knees, and hips, so much worse after long hauls that it prevented him from driving at times. He told me how once, many years before, a rheumatologist had told him that he had rheumatism and gave him prescriptions that cost over $\$ 500$ a month. He told me about the water pills someone else gave him for high blood pressure, pills he didn't take because, "they make me feel bad." He nodded yes slowly and repetitively, like a vertical metronome, when I asked him if the blood pressure pills made it difficult for him to get an erection.

Stuart's brief yet telling exposé gave me insight into the complex and confusing environment where our annual health messages to him landed. We told him lots of things not to do-not to drink alcohol, not to sit a lot, and not to use salt. We also told him lots of things to do-eat low cholesterol foods, start exercising regularly, and get a flu shot. But for a truck driver, driving night and day, it wasn't easy, he said. "I worry a lot. I live alone, got grown kids, and their problems too. Still, everyone is telling me I should take better care of myself."

He became quiet. His disclosures demanded a response, but neither of us knew exactly what to say next. I sensed a new connection forming in the momentary silence that followed, one that felt quite natural, like water trickling over rocks after a storm. I tilted my computer screen down, lowered my gaze, took a deep breath, and momentarily closed my eyes, ashamed of my initial thoughts when I entered the exam room.

"Thank you for sharing," I finally said, truly grateful for not missing an opportunity I perhaps miss too often, to slow down time in the clinic, instead of speeding it up, sometimes even before the first morning patient leaves. "Perhaps we can address your concerns by seeing you more frequently yet keeping your bills very low," I offered, and he accepted. I also agreed to provisionally sign the DOT form.

We began with a simple combination of intermittent aspirin and prednisone for his rheumatoid flares, punctuated by an occasional oxycodone, providing rapid and safe relief at an affordable price. We moved to a non-diuretic-based blood pressure treatment, and the impotence improved. We began to discuss not just the anxiety in Stuart's life, but also his hobbies and happiness. We laughed at bad jokes. We discussed his impending 65th birthday, when he knew that Medicare would kick in and provide both of us with some respite. Not unexpectedly, Stuart's blood pressure also came down. I felt better about signing off on the forms, perhaps a little more confident that Stuart would not have a sudden stroke while behind the wheel.

A month later, a week before his birthday, Stuart died suddenly, alone in his chair at home. I was alone in my office when I received the phone call asking me to sign, not the DOT form, but the death certificate. I sat for a long time, letting thoughts and emotions come and go freely. I made no effort to answer e-mails, to read articles, or to call a friend. I wiped tears with the side of my shirt. I rested my head on my arms and wondered who had found him, if he had suffered, or if I had missed something. I decided to look for potential answers to these questions in the computerized medical record and realized it was not truly my friend. It offered no solace, no comforting words or advice, even with dual screens on both sides of my desk that supposedly brought the whole picture into view. A few calls later, Stuart's sister told me that she had sent her 17-year-old son to check in on Stuart after no one answered the phone. While I offered some words of condolence, I mostly listened.

At Stuart's funeral, I was a stranger in a glorious Southern Baptist church that welcomed me into its coolness on a day when the temperature peaked at 102. There were songs of praise, solos and sermons mingling effortlessly with amens and hallelujahs, all in celebration of a life remembered through stories of fishing, hunting, and friendship, a life cut short at least a week too soon to provide lasting insurance. I began to smile, secure in the knowledge that Stuart was beloved by a large faith community. That same day the Supreme Court surprised many of us by saying that the future of health care might be better than the past, upholding provisions of the Affordable Care Act that would have allowed the Stuarts in America the opportunity to have insurance before their 65th birthday.

Would having health insurance sooner have saved Stuart? This is a question I can ask, but the answers are not straightforward. While Stuart refused some tests for cancer prevention, like colonoscopy-until recently quite expensive and with many out-of-pocket costs- he did not appear to have died from colon cancer. Perhaps Stuart ran out of his blood pressure medication, was told he had to switch to a more expensive medication at the pharmacy, or simply decided to stop the medication. Medication compliance is never easy, and decisions affecting compliance are confounded for many patients by co-pays, generics, multiple tiers, or prior authorization. Perhaps Stuart had chest pain but, knowing the cost of an emergency department visit, decided to wait it out, gambling incorrectly that it would go away. Stuart knew that despite our financial 
arrangements, he still did not have the money to afford most of his health care.

Even if he had a massive stroke or heart attack, I still believe that Stuart died in part as a result of a health care system that has a messy patchwork of regulations mixed with politics. Our health care system covers wellness exams but requires additional funds for illness; often rises in price by double digits annually and shifts increasing costs onto patients; remains difficult for most clinicians to fully understand insurance options, exchanges, and penalties; and makes increasing numbers of decisions regarding medications outside of the doctor-patient relationship. If these issues can adversely impact individuals who have access to health care, how much more so can they adversely affect the Stuarts of the world who do not-or cannot-access affordable insurance?

The Affordable Care Act came a little too late to help Stuart, but I think he would have taken solace in knowing that others will benefit where he did not.
Although not everyone experiences the same barriers to health insurance that Stuart did, we must still be prepared for-and not put blame on-the patient who sees a stream of different clinicians, crosses his arms, and only offers 1 word answers. Even with the high cost of care and difficulty of accessing many services, we must still strive for excellence in quality and continuity of care in our health care system.

As I returned to my office, I smiled with assurance that Stuart would approve (and perhaps even laugh), with his legs still swaying, if I wrote "no health insurance" as the cause on his death certificate.

To read or post commentaries in response to this article, see it online at http://www.annfammed.org/content/13/4/370.

Submitted December 17, 2014; submitted, revised, February 24, 2015; accepted March 16, 2015.

Acknowledgment: I would like to thank Jennifer Greyber for editorial assistance in preparing this manuscript.

\title{
We need an additional 44,300 primary care physicians to ensure health care for all Americans.'
}

\author{
Faculty for Tomorrow is a 2-year initiative to address the \\ shortage of family medicine faculty.
}

Be part of the solution: www.stfm.org/Foundation

1. Petterson, et al., Annals of Family Medicine, 2015 